\title{
Characterization of extended-spectrum $\beta$-lactamases and integrons in Escherichia coli isolates in a Spanish hospital
}

In the last few years, the emergence and wide dissemination of Escherichia coli strains showing resistance to broad-spectrum cephalosporins and monobactams, due to the production of extended-spectrum $\beta$-lactamases (ESBLs), has been reported. In the 1990s, early publications on ESBLs reported $b l a_{\mathrm{SHV}}$ or $b l a_{\mathrm{TEM}}$ variants, which were especially detected in Klebsiella isolates recovered in intensive care units. The situation has been changing in the last few years and CTX-M $\beta$-lactamases are an emerging mechanism of resistance, mainly among E. coli isolates (Cantón et al., 2008; Rossolini et al., 2008). More than 65 different CTX-M $\beta$ lactamases belonging to six different groups have been reported to date (Rossolini et al., 2008).

Different genetic environments might be involved in the mobilization of bla $_{\mathrm{CTX}-\mathrm{M}}$ genes. The insertion sequence ISEcpl, which is known to mobilize the sequences located at its right-end extremity, has been found upstream of a wide variety of $b l a_{\text {CTX-M }}$ genes (Poirel et al., 2008). In addition, IS26, IS10, IS5 and IS903 have been detected surrounding different $b a_{\text {CTX-M }}$ genes (Eckert et al., 2006; Poirel et al., 2008; Cartelle et al., 2004; Lartigue et al., 2004). The bla ${ }_{\text {СтХ-м }}$ genes have also been identified in complex sull-type class 1 integrons such as In60 (Sabaté et al., 2002; Riaño et al., 2006; Novais et al., 2006), or associated with a phage-related element (Oliver et al., 2005). The production of plasmidic class $\mathrm{C} \beta$-lactamases, such as CMY enzymes, or the overproduction of the chromosomal AmpC $\beta$-lactamase (Briñas et al., 2005; Caroff et al., 2000; Mulvey et al., 2005; Stapleton et al., 1999) can also be associated with broad-spectrum cephalosporin-resistance in E. coli.

The objective of this work was to carry out $\beta$-lactamase characterization for all broadspectrum cephalosporin-resistant E. coli isolates recovered during a 1 year period
(2003-2004) in a Spanish hospital, in order to determine the genetic environment of the $b l a_{\text {CTX-M }}$ genes, and their possible inclusion in integrons. The results obtained in this study were compared with previous data obtained for E. coli isolates recovered by our group in the same hospital in 2002 (Briñas et al., 2005), in order to track the evolution of ESBLs and other mechanisms of broadspectrum-cephalosporin resistance.

Among the 1376 E. coli isolates recovered from patients of the Hospital Universitario Central de Asturias (Oviedo, Spain) during a 1 year period (April 2003 to March 2004), 61 isolates (4.4\%) showed a MIC value for cefotaxime (CTX) and/or ceftazidime $(\mathrm{CAZ}) \geqslant 2 \mu \mathrm{g} \mathrm{ml}^{-1}$, and were included in this study. The origins (and numbers) of the isolates were as follows: urine (37), exudates and surgical wounds (10), blood (4), tracheobronchial aspirate (5), pus (3), bile (1) and cephalorachidian liquid (1).

Antibiotic susceptibility to amoxicillin, amoxicillin/clavulanic acid (AMC), cephalothin, cefoxitin, CTX, CAZ, cefepime, imipenem, nalidixic acid, ciprofloxacin, gentamicin, amikacin, tobramycin, fosfomycin and trimethoprim/sulfamethoxazole (SXT) was studied by agar dilution and/or the disc diffusion method (CLSI, 2007). E. coli ATCC 25922 was used as a quality control strain. To determine ESBL production, a double-disc synergy test (Jarlier et al., 1988) between AMC and CTX or CAZ was performed, and this screening test was positive in 56 isolates and negative in the remaining 5 isolates, representing 4.1 and $0.4 \%$, respectively, of the total 1376 E. coli isolates. In a previous work carried out by our group in the same hospital in 2002, the prevalence of this type of isolate was 1.4 and $0.6 \%$, respectively, among 1700 E. coli isolates (Briñas et al., 2005).

The presence of genes encoding TEM, SHV, CTX-M and CMY type $\beta$-lactamases was studied in the strains by specific PCRs (Jouini et al., 2007; Bertrand et al., 2006; Stapleton et al., 1999). All obtained amplicons were sequenced on both strands, and sequences were compared with those included in the GenBank database and on the Lahey Clinic website (http://www.lahey.org/Studies/) in order to identify the $\beta$-lactamase-encoding genes. The MICs of different $\beta$-lactams and the type of $\beta$-lactamases detected in the 56 ESBL-positive isolates are shown in Table 1 , being the following $\beta$-lactamaseencoding genes (the numbers of isolates are shown in parenthesis): $b a_{\mathrm{CTX}-\mathrm{M}-14}$ (29), bla $a_{\text {СТХ-М-9 }}(9), b l a_{\text {СтХ-М-15 }}$ (1), $b a_{\mathrm{CTX}-\mathrm{M}-32}(2), b a_{\mathrm{SHV}-12}(12), b l a_{\mathrm{SHV}-2}$ (1), bla $a_{\mathrm{TEM}-52}(1)$ and a new $b l a_{\mathrm{SHV}}$ gene (1).

The new $b l a_{\mathrm{SHV}}$ gene was characterized by a nucleotide mutation that involves one amino acid change, Gly238Ala, with respect to SHV-1 $\beta$-lactamase. The MICs of CTX and CAZ in this isolate were of 16 and $8 \mu \mathrm{g} \mathrm{ml}^{-1}$, respectively (Table 1 ). This new SHV variant has been named as SHV-102 and included in the GenBank database with the accession number EU024485. The Gly238Ala substitution was previously described in SHV-13, SHV-18 and SHV-29 ESBLs (in addition to amino acid changes at other positions), and one unique amino acid change at this position (Gly238Ser) has been reported to hydrolyse CTX (Huletsky et al., 1993).

It is interesting to note that 41 of our 56 ESBL-positive E. coli isolates $(73.2 \%)$ harboured a $\beta$-lactamase of CTX-M class, 14 isolates $(25 \%)$ a $\beta$-lactamase of SHV class (with 3 different molecular variants) and 1 isolate $(1.8 \%)$ a $\beta$-lactamase of TEM class. A gene encoding a $\beta$-lactamase of the CTX-M-9 group ( $b l a_{\text {СТХ-М-14 }}$ or $b l a_{\text {СТХ-М-9 }}$ ) was detected in 38 of the $41 b^{b l a_{\text {CTX-M }}}{ }^{-}$ containing strains $(92.6 \%)$. If these results are compared with the previous ones obtained in the same hospital (Briñas et al., 


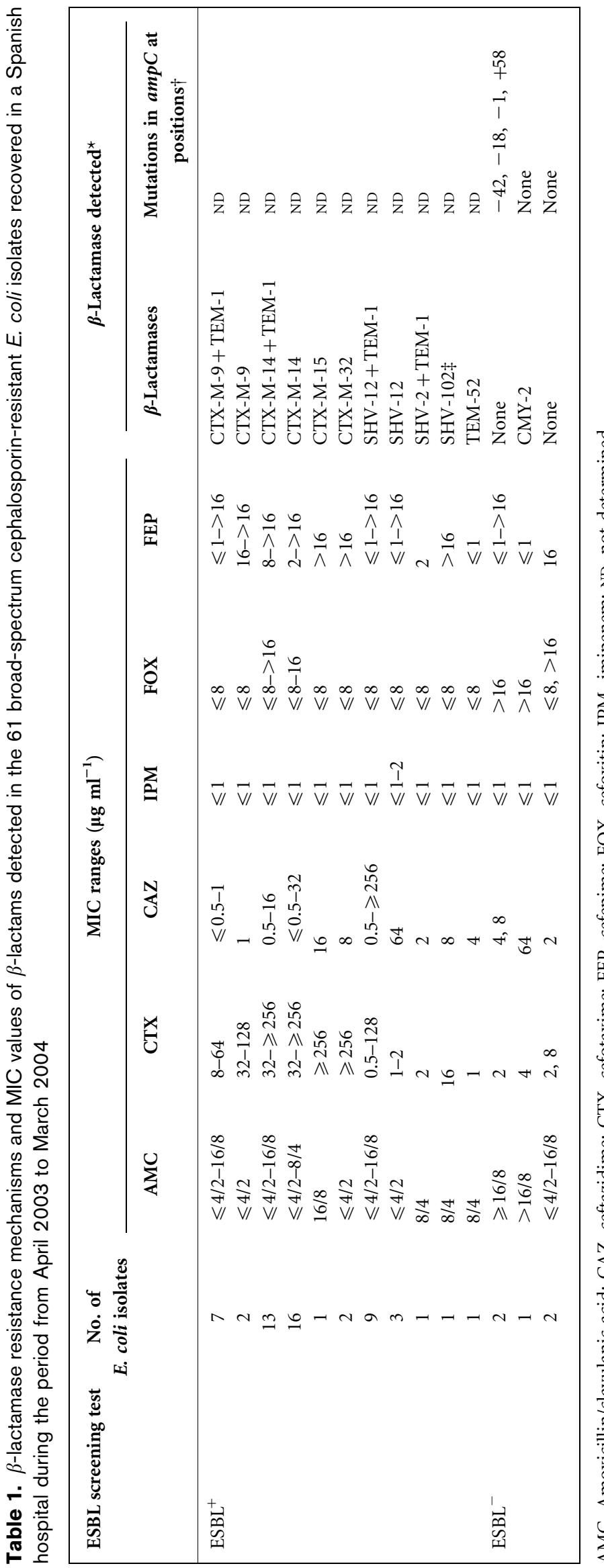

2005), the evolution shows a diversification of the ESBLs of CTX-M and SHV types. It also seems that SHV-type ESBLs are increasing in prevalence ( $12.5 \%$ in 2002 versus $25 \%$ in 2003 2004), mainly SHV-12 enzymes, and that TEM-type ESBLs are decreasing in importance ( $8.3 \%$ in 2002 versus $1.8 \%$ in 2003-2004). A similar tendency has been observed in other studies (Brasme et al., 2007; Valverde et al., 2004; Paterson et al., 2003). It would be interesting to track the evolution of these genes in the following years to detect whether this tendency is maintained.

The percentages of resistance to non- $\beta$-lactam antibiotics for our ESBL-positive isolates were as follows: nalidixic acid (64\%), ciprofloxacin $(32 \%)$, gentamicin $(18 \%)$, tobramycin $(12.5 \%)$, amikacin (9\%), SXT (66\%) and fosfomycin $(0 \%)$. High percentages of resistance to quinolones were observed among our ESBL isolates, and similar observations have been reported by other authors (Morosini et al., 2006).

The clonal relationship among the 41 $b l a_{\text {СтХ-M-containing isolates was studied }}$ by PFGE, using $X b a \mathrm{I}$ as restriction enzyme (Sáenz et al., 2004), and patterns were analysed according to reported criteria (Tenover et al., 1995). A total of 37 unrelated PFGE patterns were identified

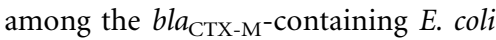
isolates, and 1 closely related or indistinguishable PFGE pattern was found in 4 of the CTX-M-positive isolates (Table 2). This high clonal diversity observed among our bla $a_{\mathrm{CTX}-\mathrm{M}^{-} \text {-containing }}$ E. coli isolates is coincident with similar results obtained in other studies (Velasco et al., 2007; Hernández et al., 2005, Ho et al., 2007; Briñas et al., 2005), indicating that the wide dissemination of the $b l a_{\mathrm{CTX}-\mathrm{M}}$ genes among E. coli isolates is mainly due to the horizontal dissemination of resistance determinants and not to dissemination of resistant clones.

Nevertheless, the clonal dissemination of CTX-M-15-producing E. coli isolates within the hospital and community has been reported, and very recently, the intercontinental emergence of $E$. coli clone O25:H4-ST131 producing CTX-M15 has been reported (Nicolas-Chanoine et al., 2008). 
Table 2. Genetic environment of CTX-M encoding genes and characterization of integrons in 41 clinical E. coli isolates of this study

\begin{tabular}{|c|c|c|c|c|c|}
\hline \multirow[t]{2}{*}{ Type of ESBL } & \multirow{2}{*}{$\begin{array}{l}\text { No. of isolates } \\
\quad(n=41)\end{array}$} & \multicolumn{2}{|c|}{ Class 1 integron } & \multirow{2}{*}{$\begin{array}{l}\text { Genetic environment } \\
\text { of } b a_{\mathrm{CTX}-\mathrm{M}} \text { genes }^{\star}\end{array}$} & \multirow{2}{*}{$\begin{array}{l}\text { Resistance phenotype to } \\
\text { non- } \beta \text {-lactam antibiotics }\end{array}$} \\
\hline & & intI1 & $\begin{array}{l}\text { Gene cassettes in the } \\
\text { variable region }\end{array}$ & & \\
\hline \multirow[t]{3}{*}{ CTX-M-9 } & 4 & + & $d f r A 16$, aadA2 & In60 & NAL-CIP-SXT \\
\hline & $3 \dagger$ & + & $d f r A 16$, aadA2 & In60 & NAL-TOB $\ddagger-G E N \ddagger-S X T$ \\
\hline & 2 & + & $d f r A 16$, aadA2 & In60 & SXT \\
\hline \multirow[t]{18}{*}{ CTX-M-14 } & 1 & + & $d f r A 1$, aadA1 & ISEcp1-IS903 & NAL-CIP-SXT \\
\hline & 1 & + & $d f r A 1, \operatorname{aad} A 1$ & ISEcp1-IS903 & NAL-SXT \\
\hline & $2 \S$ & $+\S$ & $d f r A 1$, aadA1 & ISEcp1-IS903 & NAL-SXT \\
\hline & 1 & + & $d f r A 17$, aadA5 & ISEcp1-IS903 & NAL-CIP-GEN-TOB $\ddagger-S X T$ \\
\hline & 1 & + & aadA1 & ISEcp1-IS903 & NAL-GEN-SXT \\
\hline & 1 & + & $\operatorname{aadB}, \operatorname{aad} A 1, \mathrm{cmlA} 1$ & ISEcp1-IS903 & NAL-CIP-GEN-TOB-SXT \\
\hline & 1 & - & - & ISEcp1-IS903 & NAL-CIP \\
\hline & 1 & + & $d f r A 1, \operatorname{aad} A 1$ & 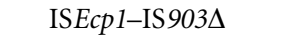 & NAL-GEN-TOB-SXT \\
\hline & 2 & + & $d f r A 1$, aadA1 & 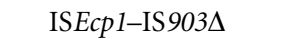 & SXT \\
\hline & 2 & + & $d f r A 17$, aadA5 & 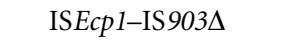 & NAL-CIP-SXT \\
\hline & 1 & + & $\operatorname{aad} A 1$ & 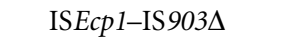 & SXT \\
\hline & 3 & - & - & 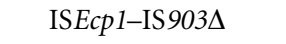 & NAL \\
\hline & 2 & + & - & 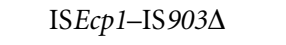 & SXT \\
\hline & 1 & - & - & 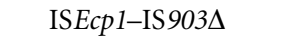 & NAL-CIP \\
\hline & 1 & - & - & 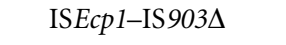 & NAL-CIP-SXT \\
\hline & 1 & - & - & 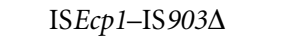 & NAL-SXT \\
\hline & 1 & + & - & 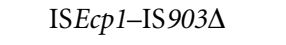 & NAL-CIP-GEN-TOB $\$-S X T$ \\
\hline & 611 & - & - & 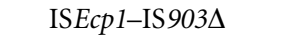 & SUSCEPTIBLE \\
\hline CTX-M-15 & 1 & + & $d f r A 17$, aadA5 & ISEcp1-orf 477 & NAL-CIP-AMK-TOB-SXT \\
\hline CTX-M-32 & 2 & - & - & ISEcp1/IS5-orf 477 & NAL \\
\hline
\end{tabular}

AMK, amikacin; CIP, ciprofloxacin; GEN, gentamicin; NAL, nalidixic acid; SXT, trimethoprim/sulfamethoxazole; TOB, tobramycin.

${ }^{\star}$ In60, the In60 integron structure was found; ISEcp1-IS903, ISEcp1 upstream of bla $a_{\text {CTX-M }}$ gene and IS903 (whole sequence) downstream; ISEcp1IS $903 \Delta$, ISEcp1 upstream of $b l a_{\mathrm{CTX}-\mathrm{M}}$ gene and IS903 (truncated sequence) downstream; ISEcp1-orf477, ISEcp1 upstream of $b l a_{\mathrm{CTX}-\mathrm{M}}$ gene and orf477 downstream; ISEcp1/IS5-orf477, ISEcp1/IS5 upstream of bla $a_{\mathrm{CTX}-\mathrm{M}}$ and orf477 downstream.

$\dagger$ Two of these isolates showed an indistinguishable PFGE pattern and the other one a closely related one.

¥Intermediate category according to the Clinical and Laboratory Standards Institute standards.

§oth isolates showed a closely related PFGE pattern and the intI1 gene truncated at the 3 ' end by the insertion of IS26.

IIFive unrelated PFGE patterns were detected among these isolates, showing two of them with an indistinguishable pattern.

The genetic environment of $b l a_{\mathrm{CTX}-\mathrm{M}}$ genes was also investigated by PCR and sequencing using specific primers designed according to reported surrounding structures (Eckert et al., 2004; Lartigue et al., 2004; Saladin et al., 2002). As shown in Table 2, all nine $b l a_{\mathrm{CTX-M-9}}$-containing isolates showed this gene inside the In60 integron, which includes the ISCR1 upstream of the $b l a_{\mathrm{CTX}-\mathrm{M}-9}$ gene and orf3-like and orf1005 downstream of this bla gene. The In60 integron has been described by Sabaté et al. (2002), and was detected later by other authors (Novais et al., 2006; Riaño et al., 2006).

All 29 E. coli isolates that contained the $b l a_{\text {CTX-M-14 }}$ gene presented the ISEcp1 upstream and IS903 downstream of this $b l a_{\mathrm{CTX}-\mathrm{M}-14}$ gene. The whole IS903 sequence was obtained in eight of the isolates, whereas a truncated IS903 was present in the remaining ones; both structures have been described by Eckert et al. (2006).

The genetic environment of the $b l a_{\mathrm{CTX}-\mathrm{M}-15}$ and $b l a_{\mathrm{CTX}-\mathrm{M}-32}$ genes detected in the three remaining $b l a_{\mathrm{CTX}-\mathrm{M}^{-c o n t a i n i n g}}$ isolates included the ISEcp 1 and the ISEcp1/IS 5 upstream of $b l a_{\mathrm{CTX}-\mathrm{M}-15}$ and $b l a_{\mathrm{CTX}-\mathrm{M}-32}$, respectively, and the orf 477 downstream of both bla genes, as has been detected by others (Eckert et al., 2006; Cartelle et al., 2004).

The detection of class 1 integrons, as well as the characterization of the gene cassettes included in their variable regions, were

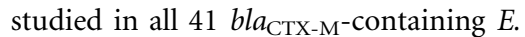
coli isolates by PCR and sequencing. The results are presented in Table 2. The intI1 and the variable region of class 1 integrons were detected in 23 of these isolates. Two of them presented the intII gene interrupted at the $3^{\prime}$ end by the insertion of the IS26 element (data not shown). Some class 1 integrons lacking a functional integrase have been described already (i.e. GenBank accession numbers AF205943 and AJ870926), although none of them are identical to our integron that presented the following composition: IS26+ int $I 1 \Delta+d f r A 1+$ aadA $1+q a c E \Delta 1+$ sull.

A wide variety of gene cassette arrangements were detected in the variable region of the class 1 integrons in these 23 
isolates: $d f r A 16+a a d A 2$ inside In60 (9 isolates), $d f r A 1+$ aadA1 (7 isolates), $d$ frA17+ aadA5 (4 isolates), aadA1 (2 isolates) and aadB + aadA $1+c m l A 1$ ( 1 isolate). In addition, the gene encoding the class 1 integrase was found in three additional isolates in which no variable region could be identified (Table 2 ). The absence of the $3^{\prime}$ conserved region (qacE $\Delta 1+$ sull genes) in these strains could explain the negative result, as has been described in other studies (Sáenz et al., 2004). The class 1 integrons detected in our study contained gene cassettes that confer resistance to streptomycin ( aadA1, aadA2, aadA5) and/or trimethoprim ( $d f r A 1, d f r A 16, d f r A 17)$. The unusual gene cassette combination $a a d B+a a d A 1+c m l A 1$ has been detected in pathogenic $E$. coli isolates from pigs, calves and humans (Bischoff et al., 2005; Chang et al., 2000; Du et al., 2005). The $a a d B$ gene confers resistance to gentamicin and the $c m l A 1$ gene provides resistance to chloramphenicol.

In addition, the presence of sull, sul2 and sul3 genes, associated with sulfamethoxazole resistance, was also analysed by PCR in all $b l a_{\text {CTX-м }}$ positive isolates (Sáenz et al., 2004), and 32 of the 41 bla $_{\text {CTX-M-containing } E \text {. coli isolates }}$ harboured the following genes: sull (24 isolates), sul2 (19 isolates) and sul3 (9 isolates), and more than one sul gene were detected in 18 of them (56\%).

In the five broad-spectrum-cephalosporinresistant and ESBL-negative isolates found in this work, the promoter and attenuator region of the chromosomal ampC gene was amplified by PCR (Briñas et al., 2005), sequenced, and compared with the same region of the E. coli K12 ampC gene. Mutations at positions $-42(\mathrm{C} \rightarrow \mathrm{T}),-18$ $(\mathrm{G} \longrightarrow \mathrm{A}),-1(\mathrm{C} \rightarrow \mathrm{T})$ and $+58(\mathrm{C} \longrightarrow \mathrm{T})$ were detected in two of the isolates (Table 1), and resistance could be associated with hyperproduction of chromosomal AmpC $\beta$-lactamase, as reported by Caroff et al. (2000) and Mulvey et al. (2005). The plasmidic CMY-2 $\beta$-lactamase was identified in another E. coli isolate and no mechanism of resistance could be found in the remaining two ESBL-negative E. coli isolates (Table 1).

In summary, our results show an important increase in the prevalence of
ESBLs among the E. coli isolates recovered in 2003-2004 in the studied hospital, with respect to a previous study carried out in 2002, the most prevalent ones being the ESBLs of the CTX-M class, especially those of the CTX-M-9 group (CTX-M-15 and CTX-M-32 were also detected, but they were a minority). In addition, it seems that ESBLs of the SHV-type are growing in importance, representing $25 \%$ of the total ESBLs detected, and a diversification of the SHV variants is occurring, which includes the identification of a new SHV-102 variant. More studies should be carried out in the future to track the evolution in time of ESBLs in isolates from different environments, countries and continents.

\section{Acknowledgements}

This work was partially supported by the project SAF2006-14207-C02-01 from the Ministry of Education and Science of Spain. L.V. was supported by a fellowship of the Spanish Ministry of Education and Science (SAF2006-14207-C02-01).

\section{Laura Vinué, ${ }^{1}$ Marta Lantero, ${ }^{2}$ Yolanda Sáenz, ${ }^{1}$ Sergio Somalo, ${ }^{1}$ Isabel de Diego, ${ }^{2}$ Francisco Pérez, ${ }^{2}$ Fernanda Ruiz-Larrea, ${ }^{1}$ Myriam Zarazaga $^{1}$ and Carmen Torres ${ }^{1}$}

${ }^{1}$ Área de Bioquímica y Biología Molecular, Departamento de Agricultura y Alimentación, Universidad de La Rioja, Logroño, Spain

${ }^{2}$ Servicio de Microbiología, Hospital Universitario Central de Asturias, Oviedo, Spain

\section{Correspondence: Carmen Torres (carmen.torres@unirioja.es)}

Bertrand, S., Weill, F. X., Cloeckaert, A., Vrints, M., Mairiaux, E., Praud, K., Dierick, K., Wildemauve, C., Godard, C. \& other authors (2006). Clonal emergence of extendedspectrum $\beta$-lactamase (CTX-M-2)-producing Salmonella enterica serovar Virchow isolates with reduced susceptibilities to ciprofloxacin among poultry and humans in Belgium and France (2000 to 2003). J Clin Microbiol 44, 2897-2903.

Bischoff, K. M., White, D. G., Hume, M. E., Poole, T. L. \& Nisbet, D. J. (2005). The chloramphenicol resistance gene $\mathrm{cmlA}$ is disseminated on transferable plasmids that confer multiple-drug resistance in swine Escherichia coli. FEMS Microbiol Lett 243, 285-291.
Brasme, L., Nordmann, P., Fidel, F., Lartigue, M. F., Bajolet, O., Poirel, L., Forte, D., VernetGarnier, V., Madoux, J. \& other authors (2007). Incidence of class $\mathrm{A}$ extended-spectrum $\beta$ lactamases in Champagne-Ardenne (France): a 1 year prospective study. J Antimicrob Chemother 60, 956-964.

Briñas, L., Lantero, M., Diego, I., Álvarez, M., Zarazaga, M. \& Torres, C. (2005). Mechanisms of resistance to broad-spectrum-cephalosporins in Escherichia coli isolates recovered in a Spanish hospital. J Antimicrob Chemother 56, 1107-1110.

Cantón, R., Novais, A., Valverde, A., Machado, E., Peixe, L., Baquero, F. \& Coque, T. M. (2008). Prevalence and spread of extended-spectrum $\beta$ lactamase-producing Enterobacteriaceae in Europe. Clin Microbiol Infect 14, 144-153.

Caroff, N., Esparze, E., Gautreau, D., Richet, H. \& Reynaud, A. (2000). Analysis of the effect of -42 and -32 ampC promoter mutations in clinical isolates of Escherichia coli

hyperproducing AmpC. J Antimicrob Chemother 45, 783-788.

Cartelle, M., Tomas, M. M., Molina, F., Moure, R., Villanueva, R. \& Bou, G. (2004). High-level resistance to ceftazidime conferred by a novel enzyme, CTX-M-32, derived from CTX-M-1 through a single Asp240-Gly substitution. Antimicrob Agents Chemother 48, 2308-2313.

Chang, C. Y., Chang, L. L., Chang, Y. H., Lee, T. M. \& Chang, S. F. (2000). Characterisation of drug resistance gene cassettes associated with class 1 integrons in clinical isolates of Escherichia coli from Taiwan, ROC. J Med Microbiol 49, 1097-1102.

CLSI (2007). Performance Standards for Antimicrobial Susceptibility Testing, 17th informational supplement, M100-S17. Wayne. PA: Clinical and Laboratory Standards Institute.

Du, X., Shen, Z., Wu, B., Xia, S. \& Shen, J. (2005). Characterization of class 1 integronsmediated antibiotic resistance among calf pathogenic Escherichia coli. FEMS Microbiol Lett 245, 295-298.

Eckert, C., Gautier, V., Saladin-Allard, M., Hidri, N., Verdet, C., Ould-Hocine, Z., Barnaud, G., Delisle, F., Rossier, A. \& other authors (2004). Dissemination of CTX-M-type $\beta$-lactamases among clinical isolates of Enterobacteriaceae in Paris, France. Antimicrob Agents Chemother 48, 1249-1255.

Eckert, C., Gautier, V. \& Arlet, G. (2006). DNA sequence analysis of the genetic environment of various $b a_{\text {СTX-м }}$ genes. J Antimicrob Chemother 57, 14-23.

Hernández, J. R., Martínez-Martínez, L., Cantón, R., Coque, T. M., Pascual, A. \& the Spanish Group for Nosocomial Infections (GEIH) (2005). Nationwide study of Escherichia coli and Klebsiella pneumoniae producing extended-spectrum $\beta$-lactamases in Spain. Antimicrob Agents Chemother 49,

2122-2125. 
Ho, P. L., Poon, W. W. N., Loke, S. L., Leung, M. S. T., Chow, K. H., Wong, R. C. W., Yip, K. S., Lai, E. L. \& Tsang, K. W. T. on behalf of the COMBAT Study Group (2007). Community emergence of CTX-M type extended-spectrum $\beta$-lactamases among urinary Escherichia coli from women. J Antimicrob Chemother 60, 140144.

Huletsky, A., Knox, J. R. \& Levesque, R. C. (1993). Role of Ser-238 and Lys-240 in the hydrolysis of third-generation cephalosporins by SHV-type $\beta$-lactamases probed by site-directed mutagenesis and three-dimensional modeling. J Biol Chem 268, 3690-3697.

Jarlier, V., Nicola, M. H., Fournier, G. \& Philippon, A. (1988). Extended broad-spectrum $\beta$-lactamases conferring transferable resistance to newer $\beta$-lactam agents in Enterobacteriaceae: hospital prevalence and susceptibility patterns. Rev Infect Dis 10, 867-878.

Jouini, A., Vinué, L., Slama, K. B., Sáenz, Y., Klibi, N., Hammami, S., Boudabous, A. \& Torres, C. (2007). Characterization of CTX-M and SHV extended-spectrum $\beta$-lactamases and associated resistance genes in Escherichia coli strains of food samples in Tunisia. J Antimicrob Chemother 60, 1137-1141.

Lartigue, M. F., Poirel, L. \& Nordmann, P. (2004). Diversity of genetic environment of

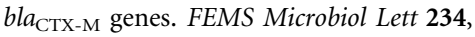
201-207.

Morosini, M. I., García-Castillo, M., Coque, T. M., Valverde, A., Novais, A., Loza, E., Baquero, F. \& Cantón, R. (2006). Antibiotic coresistance in extended-spectrum- $\beta$-lactamaseproducing Enterobacteriaceae and in vitro activity of tigecycline. Antimicrob Agents Chemother 50, 2695-2699.

Mulvey, M. R., Bryce, E., Boyd, D. A., Ofner-Agostini, M., Land, A. M., Simor, A. E. \& Paton, S. (2005). Molecular characterization of cefoxitin-resistant Escherichia coli from Canadian Hospitals. Antimicrob Agents Chemother 49, 358-365.
Nicolas-Chanoine, M. H., Blanco, J., LeflonGuibout, V., Demarty, R., Alonso, M. P., Caniça, M. M., Park, Y. J., Lavigne, J. P., Pitout, J. \& Johnson, J. R. (2008). Intercontinental emergence of Escherichia coli clone $\mathrm{O} 25$ : H4ST131 producing CTX-M-15. J Antimicrob Chemother 61, 273-281.

Novais, A., Cantón, R., Valverde, A., Machado, E., Galán, J. C., Peixe, L., Carattoli, A., Baquero, F. \& Coque, T. M. (2006). Dissemination and persistence of $b l a_{\mathrm{CTX}-\mathrm{M}-9}$ are linked to class 1 integrons containing CR1 associated with defective transposon derivatives from $\mathrm{Tn} 402$ located in early antibiotic resistance plasmids of IncH12, IncP1- $\alpha$, and IncFI groups. Antimicrob Agents Chemother 50, 2741-2750.

Oliver, A., Coque, T. M., Alonso, D., Valverde, A., Baquero, F. \& Cantón, R. (2005). CTX-M-10 linked to a phage-related element is widely disseminated among Enterobacteriaceae in a Spanish hospital. Antimicrob Agents Chemother 49, 1567-1571

Paterson, D. L., Hujer, K. M., Hujer, A. M., Yeiser, B., Bonomo, M. D., Rice, L. B., Bonomo, R. A. \& the International Klebsiella Study Group (2003). Extended-spectrum $\beta$-lactamases in Klebsiella pneumoniae bloodstream isolates from seven countries: dominance and widespread prevalence of SHV- and CTX-M-type $\beta$-lactamases. Antimicrob Agents Chemother 47, 3554-3560.

Poirel, L., Naas, T. \& Nordmann, P. (2008). Genetic support of extended-spectrum $\beta$ lactamases. Clin Microbiol Infect 14, 75-81.

Riaño, I., Moreno, M. A., Teshager, T., Sáenz, Y., Dominguez, L. \& Torres, C. (2006). Detection and characterization of extended-spectrum $\beta$-lactamases in Salmonella enterica strains of healthy food animals in Spain. J Antimicrob Chemother 58, 844-847.

Rossolini, G. M., D’Andrea, M. M. \& Mugnaioli, C. (2008). The spread of CTX-M-type extendedspectrum $\beta$-lactamases. Clin Microbiol Infect 14, 33-41.
Sabaté, M., Navarro, F., Miró, E., Campoy, S. Mirelis, B., Barbé, L. \& Prats, G. (2002). Novel complex sull-type integron in Escherichia coli carrying bla $a_{\text {СTХ-м-9. Antimicrob Agents }}$ Chemother 46, 2656-2661.

Sáenz, Y., Briñas, L., Domínguez, E., Ruiz, J., Zarazaga, M., Vila, J. \& Torres, C. (2004). Mechanisms of resistance in multiple-antibioticresistant Escherichia coli strains of human, animal, and food origins. Antimicrob Agents Chemother 48, 3996-4001.

Saladin, M., Cao, V. T. B., Lambert, T., Donay, J. L., Herrmann, J. L., Ould-Hocine, Z., Verdet, C., Delisle, F., Philippon, A. \& Arlet, G. (2002). Diversity of CTX-M $\beta$-lactamases and their promoter regions from Enterobacteriaceae isolated in three Parisian hospitals. FEMS Microbiol Lett 209, 161-168.

Stapleton, P. D., Shannon, K. P. \& French, G. L. (1999). Carbapenem resistance in Escherichia coli associated with plasmid-determined CMY-4 $\beta$-lactamase production and loss of an outer membrane protein. Antimicrob Agents Chemother 43, 1206-1210.

Tenover, F. C., Arbeit, R. D., Goering, R. V., Mickelsen, P. A., Murray, B. E., Persing, D. H. \& Swaminathan, B. (1995). Interpreting chromosomal DNA restriction patterns produced by pulsed-field gel electrophoresis: criteria for bacterial strain typing. J Clin Microbiol 33, 2233-2239.

Valverde, A., Coque, T. M., Sánchez-Moreno, M. P., Rollán, A., Baquero, F. \& Cantón, R. (2004). Dramatic increase in prevalence of fecal carriage of extended-spectrum $\beta$-lactamase-producing Enterobacteriaceae during nonoutbreak situations in Spain. J Clin Microbiol 42, 4769-4775.

Velasco, C., Romero, L., Martínez, J. M., Rodríguez-Baño, J. \& Pascual, A. (2007). Analysis of plasmids encoding extendedspectrum $\beta$-lactamases (ESBLs) from Escherichia coli isolated from non-hospitalised patients in Seville. Int J Antimicrob Agents 29, 89-92. 